\title{
Too Modest a Proposal? Work Rights under the Proposed Constitution Aotearoa
}

\author{
JONATHAN BARRETT* ${ }^{*}$ and AMANDA REILLY**
}

\begin{abstract}
Constitutional lawyers, Sir Geoffrey Palmer and Andrew Butler, have sought to spark debate by publishing a proposed constitution, including a Bill of Rights, for Aotearoa New Zealand (Constitution Aotearoa). The current New Zealand Bill of Rights Act 1990, which is neither entrenched nor superior legislation, guarantees freedom of association but is otherwise silent on work rights. In addition to affirming freedom of association, and freedom from forced labour, Constitution Aotearoa includes three provisions expressly relating to work rights. These are the non-justiciable rights to resort to collective action in the event of a conflict of interest; to satisfactory health and safety conditions; and to earn one's living in an occupation freely entered into. Is this too modest a proposal which misses the opportunity to provide strong and abiding, fundamental rights for everyone who works? This article seeks to answer that question by drawing on other bills of rights, including those of Canada, Germany and South Africa, and the Charter of Fundamental Rights of the European Union, to consider the work rights which might be included in a new constitution for New Zealand.
\end{abstract}

\section{Introduction}

Sir Geoffrey Palmer and Andrew Butler have sought to spark debate by publishing a proposed constitution, including an entrenched, legislatively-superior Bill of Rights, for Aotearoa New Zealand (Constitution Aotearoa). In addition to guarantees of freedom of association, ${ }^{1}$ and freedom from forced labour, ${ }^{2}$ article 106 of Constitution Aotearoa includes three provisions expressly relating to work rights (and three other socio-economic rights). These work rights are the non-justiciable rights to resort to collective action in the event of a conflict of interest; to satisfactory health and safety conditions; and to earn one's living in an occupation freely entered into. Are these proposals too modest and miss the opportunity to provide strong and abiding, fundamental rights for everyone who works? This article seeks to answer that question by drawing on other bills of rights - those of Canada, Germany and South Africa, ${ }^{3}$ and the Charter of Fundamental Rights of the European Union - to consider which work rights might be included in a new constitution and how that should be done.

This article is structured as follows: firstly, the work rights proposed in Constitution Aotearoa are outlined; secondly, a brief survey of work rights enshrined in other rights charters is

\footnotetext{
* Dr. Jonathan Barrett, Senior Lecturer, School of Accounting and Commercial Law, Victoria University of Wellington, New Zealand

** Dr Amanda Reilly, Senior Lecturer, School of Accounting and Commercial Law, Victoria University of Wellington, New Zealand

1 Geoffrey Palmer and Andrew Butler A Constitution for Aotearoa New Zealand (Victoria University Press, Wellington, 2016) at 65 (Constitution Aotearoa, art 91).

2 At 64 (Constitution Aotearoa, art 85).

3 We are aware that other constitutions, say, those of post-Soviet countries may also be of interest but have limited our research in the interests of manageability.
} 
conducted. This survey informs the analysis of the proposed work rights in the next section which then leads to the conclusion.

\section{Constitution Aotearoa and work rights}

Constitution Aotearoa includes two civil and political (International Covenant on Civil and Political Rights (ICCPR ${ }^{4}$-style) rights associated with the workplace. Article 85 provides "[e]veryone has the right not to be held in slavery or servitude, or required to perform forced or compulsory labour" and article 91 provides "[e]veryone has the right to freedom of association". 5 Article 106 provides for six socio-economic (International Covenant on Economic, Social and Cultural Rights (ICESCR) ${ }^{6}$-style) rights, including:

d) the right of every worker to resort to collective action in the event of a conflict of interests, including the right to strike:

e) the right of every worker to enjoy satisfactory health and safety conditions in their working environment:

f) the right of workers to earn their living in an occupation freely entered upon.

Unlike ICCPR-style rights, these ICESCR-style rights are qualified and are essentially instrumental in nature. Thus, despite the terminology of enforceable rights being used, these "rights" are, in fact, "non-justiciable principles". Further, the preamble to the socio-economic section commences with the phrase "[i]n making provision for the social and economic welfare of the people", which implies that the work rights identified are not considered ends in themselves. It is arguable that many other rights, such as freedom of expression or the right to vote, are mere instruments for achieving autonomy, personhood or dignity. ${ }^{7}$ Indeed, drawing a long bow, we might argue that freedom from slavery is not in itself an inherent good, but is asserted because slavery obviates realisation of a Kantian conception of autonomy. ${ }^{8}$ Nevertheless, such rights that are typically seen as ends in themselves are not couched in instrumental terms. Work rights should be included in the same category.

4 UN General Assembly, International Covenant on Civil and Political Rights, 16 December 1966, United Nations, Treaty Series, vol. 999, p. 171 [ICCPR].

5 Other rights, such as equality, privacy, freedom of expression and so forth, may also be relevant to the workplace.

A right to freedom of association may also be fence-sitting on the part of Palmer and Butler. Employers have traditionally argued for freedom of association, whereas "the trade unions emphasize the right to associate along with its derivatives". See Guy Mundlak "Human Rights and Labor Rights: Why Don't the Two Tracks Meet?" (2012) 34 Comp Lab L \& Pol'y J 217 at 232. Palmer and Butler appear to elide the long-established jurisprudential distinction between a freedom (or liberty) and a right. Glanville Williams defines a 'liberty' as "any occasion on which an act or omission is not a breach of duty". See Glanville Williams "The Concept of Legal Liberty" (1956) 56(8) Colum L Rev 1129 at 1129. "When a liberty is stated, it is generally by way of expressing the limits of a legal duty. Thus freedom of speech, which is a liberty, represents the limits of the duty not to utter defamation, blasphemy, obscenity, and sedition." At 1130 .

6 UN General Assembly, International Covenant on Economic, Social and Cultural Rights, 16 December 1966, United Nations, Treaty Series, vol. 993, p. 3 [ICESCR].

7 See, for example, Stanley Fish There's No Such Thing As Free Speech: And It's a Good Thing, Too (Oxford University Press, New York, 1994).

8 See Robert Johnson and Adam Cureton “Kant's Moral Philosophy” in Edward N Zalta (ed) The Stanford Encyclopedia of Philosophy (Fall 2017 ed) <www.plato.stanford.edu>. 
Palmer and Butler explain their choice thus: ${ }^{9}$

We have considered a number of overseas models and have decided that the best approach for New Zealand is to explicitly recognise a number of socio-economic rights in Constitution Aotearoa, but make them explicitly non-justiciable (capable of being settled by law or the action of a court). So the courts will not be able to enforce them; but citizens will be able to draw on them to make State institutions accountable.

When introduced, New Zealand Bill of Rights Act 1990 (NZBORA), for which Palmer was the patron, was described as a "Clayton's Bill of Rights". ${ }^{10}$ Based on the tagline for a nonalcoholic drink ("It's the drink I have when I'm not having a drink"), it was said to be "the bill of rights you have when you don't want a bill of rights". ${ }^{11}$ It appears that Palmer and Butler may be perpetuating such fence-sitting or textual legerdemain with regard to the work rights affirmed in Constitution Aotearoa.

NZBORA is not a code. Section 28 provides: $:^{12}$

An existing right or freedom shall not be held to be abrogated or restricted by reason only that the right or freedom is not included in this Bill of Rights or is included only in part.

Important work rights, which represent New Zealand's commitment to human rights instruments, including International Labour Organisation (ILO) conventions, ${ }^{13}$ are included in legislation, notably the Employment Relations Act 2000. ${ }^{14}$ A key purpose of Constitution Aotearoa is to "[s]et out the rules, principles and processes about government in one document so they are accessible, available and clear". ${ }^{15}$ But this desideratum does not extend to rights. Article 80 continues the uncertainty of NZBORA by providing other rights and freedoms are not affected by the new constitution. ${ }^{16}$ It is not implausible to conclude that the authors of

$9 \quad$ Palmer and Butler, above n 1, at 171.

10 See David Haywood “Clayton's Bill of Rights” Public Address (27 March 2006) <www.publicaddress.net>.

11 Haywood, above n 10.

12 NZBORA, s 28.

In a dissenting judgement in Brooker $v$ Police [2007] NZSC 3 at [166], in particular, Thomas J persuasively argued that privacy (not included in NZBORA) was a principle that ought to be balanced against freedom of expression (included in NZBORA).

13 See Ministry of Business, Innovation \& Employment International Labour Conventions Ratified by New Zealand (2015) <www.mbie.govt.nz>.

14 An object of the Act is "to promote observance in New Zealand of the principles underlying International Labour Organisation Convention 87 on Freedom of Association, and Convention 98 on the Right to Organise and Bargain Collectively". See Employment Relations Act 2000, s 3(b). A purpose of the Employment Relations Act 2000 (s 3(b)) is "to promote observance in New Zealand of the principles underlying International Labour Organisation Convention 87 on Freedom of Association, and Convention 98 on the Right to Organise and Bargain Collectively.” Margaret Wilson (then Minister of Labour) explains: the Employment Relations Act was an attempt to comply with both Conventions 87 and 98. I suspected the attempt would fail because of the continuing restrictions on the right to strike when bargaining collectively, for example, secondary boycotts. This turned out to be correct. Although there were extensive discussions with the ILO officials, the ILO would only agree that the Act complied with Convention 98 but not 87 .

See Margaret Wilson "ILO - Role New Zealand Government: Reflections of a Former Minister of Labour" (2000) 35(3) NZJER 6 (unpaged). Wilson does not discuss C138.

15 Palmer and Butler, above n 1, 25.

16 There may be prudence in this approach but if the drafter says "this is the bill of rights but we may not have included all rights", Courts and others are not prompted to focus their minds on rights that are not expressly included. 
Constitution Aotearoa have concerned themselves principally with the structure of government, but have not taken rights into serious consideration.

\section{Work rights under selected human rights documents}

This part of the article considers corresponding provisions from selected human rights instruments with a view to illuminating the relevant provisions of Constitution Aotearoa. With regard to universal human rights, it is pertinent to recall the following statement in the Vienna Declaration and Programme of Action: ${ }^{17}$

All human rights are universal, indivisible and interdependent and interrelated. The international community must treat human rights globally in a fair and equal manner, on the same footing, and with the same emphasis. While the significance of national and regional particularities and various historical, cultural and religious backgrounds must be borne in mind, it is the duty of States, regardless of their political, economic and cultural systems, to promote and protect all human rights and fundamental freedoms.

In other words, a human rights state (Rechtsstaat), such as New Zealand, may not be selective and treat human rights as if they were options on a cafeteria menu. ${ }^{18}$ Yet the labour rights, which are enshrined in the principal human rights instruments, are commonly relegated below other rights. Guy Mundlak argues: ${ }^{19}$

There is no disjuncture between labour rights and human rights. The parallel tracks [identified by Kevin Kolben] emerge from the fact that different agents draw on these rights in different ways. Consequently, the relationship between ... labor rights or human rights, requires asking: who uses the human rights discourse (or, alternatively, a labor rights discourse), how and why.

In the workplace, human dignity is often at risk, and so asserting rights which preserve and promote personhood is critical.

\section{i. Universal Declaration of Human Rights}

Article 4 of the Universal Declaration of Human Rights (UDHR) ${ }^{20}$ prohibits slavery and servitude. Article 20 guarantees "freedom of peaceable assembly and association", including the right not to be compelled to join an association. Freedom of association does not, of course, only relate to trade unions, ${ }^{21}$ although, in practice, they are an important manifestation of that

17 UN General Assembly, Vienna Declaration and Programme of Action, 12 July 1993, A/CONF.157/23 at $[5]$.

18 Paula Bennett, then Minister of Police, outraged many when she argued that gang members should have fewer human rights than other members of society. See, for example, Isaac Davison "Bill English: Paula Bennett wrongly described National's anti-gang policy" The New Zealand Herald (online ed, Auckland, 4 September 2017).

19 Mundlak, above n 5, at 230. See also Judy Fudge "The New Discourse of Labor Rights: From Social to Fundamental Rights?" (2007) 29 Comp Lab L \& Pol'y J 29; Larry Savage "Workers' Rights as Human Rights" (2009) 34(1) Labor Stud J 8; Kevin Kolben “Labor Rights as Human Rights?” (2010) 50 Va J Int'l L 449; Virginia Mantouvalou “Are Labour Rights Human Rights?” (2012) 3 ELLJ 151.

20 UN General Assembly, Universal Declaration of Human Rights, 10 December 1948, 217 A (III) [UDHR].

21 Totalitarian states have historically suppressed civil society associations and brought them under state control. See S Wojciech Sokolowski "Philanthropic Leadership in Totalitarian and Communist Countries" 
liberty. It is notable, then, that article 23(4) specifically grants a person "the right to form and to join trade unions for the protection of his interests". This article includes other important work rights, those being, "to work, to free choice of employment, to just and favourable conditions of work and to protection against unemployment"; 22 "to equal pay for equal work", 23 and "to just and favourable remuneration ensuring for himself and his family an existence worthy of human dignity, and supplemented, if necessary, by other means of social protection". ${ }^{24}$ Finally, under article 24, "[e]veryone has the right to rest and leisure, including reasonable limitation of working hours and periodic holidays with pay".

As a declaration, the UDHR is primarily of moral force, and generally its principles must be expressed in the more specific language of treaties to legally bind ratifying countries. ${ }^{25}$ This outcome is achieved by the ICCPR and the ICESCR.

\section{ii. ICCPR}

Article 8 amplifies the principle of freedom from slavery and servitude into a legally comprehensible form, and article 26 prohibits traditional forms of discrimination. Unlike the UDHR, the rights of peaceful assembly and to freedom of association are covered in separate provisions (articles 21 and 22). Article 22 provides:

1. Everyone shall have the right to freedom of association with others, including the right to form and join trade unions for the protection of his interests ...

2. No restrictions may be placed on the exercise of this right other than those which are prescribed by law and which are necessary in a democratic society in the interests of national security or public safety, public order (ordre public), the protection of public health or morals or the protection of the rights and freedoms of others. This article shall not prevent the imposition of lawful restrictions on members of the armed forces and of the police in their exercise of this right.

3. Nothing in this article shall authorize States Parties to the International Labour Organisation Convention of 1948 concerning Freedom of Association and Protection of the Right to Organize to take legislative measures which would prejudice, or to apply the law in such a manner as to prejudice, the guarantees provided for in that Convention.

Virginia Leary observes that ${ }^{26}$

in Kathryn A Agard Leadership in Nonprofit Organizations: A Reference Handbook, Volume 1 (Sage, Thousand Oaks (Cal), 2011) 138 at 142.

22 UDHR, art 23(1).

23 At art 23(2).

24 At art 23(3).

25 See Human Rights Commission Human Rights in New Zealand Ngā Tika Tangata O Aotearoa (2010) at 14 <www.justice.govt.nz>.

The UDHR also records peremptory norms of international law. A peremptory norm of general international law (jus cogens) is "a norm accepted and recognized by the international community of States as a whole as a norm from which no derogation is permitted and which can be modified only by a subsequent norm of general international law having the same character". See Vienna Convention on the Law of Treaties (23 May 1969) 1155 UNTS 331, entered into force 27 January 1980, art 53. Racial discrimination, for example, is contrary to jus cogens.

26 See Virginia A Leary “The Paradox of Workers' Rights as Human Rights" in Lance A Compa and Stephen F Diamond (eds) The Paradox of Workers' Rights as Human Rights (University of Pennsylvania Press, Philadelphia, 1996, 2003 ed) 22 at 29. 
...membership of the ILO implies a commitment to freedom of association, regardless of whether the relevant ILO conventions on freedom of association have been ratified. This commitment is explicit in the [1919] ILO constitution and the [1944 ILO] Declaration of Philadelphia.

\section{iii. ICESCR}

Article 6 recognises the right to work, including occupational choice. Signatory states are expected to pursue this right through measures including: ${ }^{27}$

...technical and vocational guidance and training programmes, policies and techniques to achieve steady economic, social and cultural development and full and productive employment under conditions safeguarding fundamental political and economic freedoms to the individual.

Article 7 concerns "just and favourable conditions of work". In particular, states are expected to ensure workers are remunerated through: ${ }^{28}$

(i) Fair wages and equal remuneration for work of equal value without distinction of any kind, in particular women being guaranteed conditions of work not inferior to those enjoyed by men, with equal pay for equal work;

(ii) A decent living for themselves and their families.

Furthermore, workers are guaranteed "[s]afe and healthy working conditions",29, equal opportunities for promotion, and rest and holidays. Article 8 sets out in detail rules on trade union membership.

\section{Germany}

Under article 9(3) of the German Basic Law: ${ }^{30}$

The right to form associations to safeguard and improve working and economic conditions shall be guaranteed to every individual and to every occupation or profession. Agreements that restrict or seek to impair this right shall be null and void; measures directed to this end shall be unlawful.

Workers are also entitled to choose not to join a union. ${ }^{31}$ Article 12 guarantees occupational freedom, and generally prohibits forced labour. Article 139 is a Sabbatarian guarantee but is partly justified on the grounds of "rest from work". ${ }^{32}$ While the work rights in the Basic Law are not extensive, it may be noted that German law has a monist approach to international

27 ICESCR, art 6(2).

28 At art 7(a)(i)-(ii).

29 At art 7(a)(iii).

30 Basic Law for the Federal Republic of Germany in the revised version published in the Federal Law Gazette Part III, classification number 100-1, as last amended by Article 1 of the Act of 23 December 2014 (Federal Law Gazette I p. 2438) [Translated by Christian Tomuschat and David P Currie].

31 Martin Brassey and Carole Cooper "Labour Relations" in Matthew Chaskalson and others (eds) Constitutional Law of South Africa (Juta \& Co, Cape Town, 1996) 30-1 at 30-25.

32 For an overview of German labour law, see Nicole Elert and Christopher T Brooks German Employment Law: 618 Questions Frequently Asked by Foreigners (De Gruyter, Berlin, 2014). 
treaties. ${ }^{33}$ Broadly, then, once ratified, international treaties are automatically incorporated into German law, and enjoy a status on par with legislation, but a lower status than the constitution. ${ }^{34}$

\section{Canada}

The Canadian Charter of Rights and Freedoms (the Charter) ${ }^{35}$ is particularly relevant for New Zealand since it was the model for NZBORA, ${ }^{36}$ albeit one imperfectly realised due to New Zealand's unwillingness to surrender Parliamentary sovereignty. Despite Canada's ratification of the three principal human rights instruments, ${ }^{37}$ the Charter is narrow in its scope and privileges civil and political rights. ${ }^{38}$ With regard to work rights, section 2(d) is most relevant inasmuch as it guarantees freedom of association. Furthermore, section 15 prohibits discrimination on the usual grounds. ${ }^{39}$

Soon after the adoption of the Charter, the Supreme Court of Canada held that freedom of association is an individual right which does not entrench the right to bargain collectively. ${ }^{40}$ Following 'the Labour Trilogy cases', ${ }^{41}$ for almost 30 years, it was law that the Charter does not guarantee a right to strike. However, a new trilogy of Supreme Court cases has reversed those decisions. ${ }^{42}$

Craig Neuman criticises the new trilogy on the following grounds: ${ }^{43}$

33 For monists, domestic and international law are both parts of a single global legal system. See Ian Brownlie Principles of Public International Law (7th ed, Oxford University Press, Oxford, 2008) at 31-33.

34 David Sloss "Domestic Application of Treaties" (2011).

On the relationship between the Basic Law and the Treaty on European Union see Roman Kwiecien "The Primacy of European Union Law over National Law Under the Constitutional Treaty" (2005) 6(11) Ger LJ 1479.

35 Constitution Act 1982 (Canada), part 1

36 See Susan Glazebrook "The New Zealand Bill of Rights Act 1990: its operation and effectiveness" Paper presented at the South Australian State Legal Convention, Adelaide, 22 and 23 July 2004. The charter was also influential on the development of the South African Bill of Rights. See John Dugard "A Bill of Rights for South Africa" (1990) 23(3) Cornell Int'1 LJ 441.

37 In the orthodox view, Canada is a dualist country. See Elisabeth Eid Interaction between International and Domestic Human Rights Law: A Canadian Perspective (2001) <www.icclr.law.ubc.ca>.

38 Compare with Quebec's Charter of Human Rights and Freedoms, RSQ c C-12, article 46 of which provides: "Every person who works has a right, in accordance with the law, to fair and reasonable conditions of employment which have proper regard for his health, safety and physical well-being."

39 On labour rights in Canada, see Donald D Carter et al Labour law in Canada (5th ed, Kluwer International, The Hague, 2002); Judy Fudge "Constitutionalizing Labour Rights in Canada and Europe: Freedom of Association, Collective Bargaining, and Strikes" (2005) 68(1) Current Legal Problems 267.

40 See Professional Institute of the Public Service of Canada v Northwest Territories (Commissioners) (1990) $72 \operatorname{DLR}\left(4^{\text {th }}\right) 1$.

41 Reference Re Public Service Employee Relations Act (Alberta) [1987] 1 SCR 313; Public Service Alliance of Canada v Canada [1987] 1 SCR 424; Retail, Wholesale and Department Store Union v Saskatchewan [1987] 1 SCR 460.

42 Mounted Police Association of Ontario v Canada (AG) 2015 SCC 1, [2015] 1 SCR 3; Meredith v Canada (AG) 2015 SCC 2, [2015] 1 SCR 125; Saskatchewan Federation of Labour v Saskatchewan 2015 SCC 4, [2015] 1 SCR 245. For a discussion, see Canadian Foundation for Labour Rights 2015 New Labour Trilogy CFLR Forum Report (2015).

43 Craig Neuman "The Supreme Court's New Labour Trilogy: Momentous Decisions and a Modest Critique" (2016) 25(2) Constitutional Forum constitutionnel 17 at 17.

The Supreme Court generally follows a "living tree" approach to the Constitution, rather than originalism. See WJ Waluchow "Democracy and the living tree Constitution” (2011) 59(4) Drake L Rev 1001. 
it ignores the reasonably clear intent of the drafters of the Charter; (2) it has been inconsistent and unpredictable, producing destabilizing effects; and, (3) it usurps to the judiciary a role in regulating labour relations that is better left to legislators.

Since Canada has a complex labour jurisprudence and a large body of sophisticated academic analysis, we are reluctant to make comment on the Charter and the case law generated by section 2(d) in relation to freedom of association and trade union membership and activity. Nevertheless, from a necessarily superficial observation of Canadian legislation, case law and commentary, which has been conducted instrumentally with the narrow purpose of illuminating Constitution Aotearoa, we suggest:

First, that a country's constitution should correspond with its international promises. Canada is obliged in terms of its general UN and specific ILO commitments to promote collective bargaining and to guarantee the right to strike under appropriate circumstances. ${ }^{44}$ Notwithstanding jurisprudential concerns, ${ }^{45}$ in deciding the new trilogy of cases, the Supreme Court has recognised that collective action is a critical instrument for achieving worker dignity. At a level of fundamental principle, this brings Canadian law back in line with the country's international human rights undertakings. ${ }^{46}$

Second, the early cases, rather than the later cases, caused uncertainty by denying a right which is fundamentally necessary for workers if they are to pursue their interests. What use is the freedom to join a trade union if that union is unable to bargain collectively and ultimately to strike? It was obvious that unionised workers would persist in asserting the right to bargain collectively - that is why people have formed trade unions from the time of the Tolpuddle Martyrs.

Third, it is uncontroversial to argue that courts are not well equipped to set labour policy. In the Alberta public service case, ${ }^{47}$ McIntyre J observed: ${ }^{48}$

Our experience with labour relation has shown that the courts, as a general rule, are not the best arbiters of disputes which arise from time to time ... judges do not have the expert knowledge always helpful and sometimes necessary in the resolution of labour problems.

But the issue of the right to strike is not a quotidian dispute which arises from time to time, such as the timing of meal breaks or hourly wage rates, rather it is a matter of enabling fundamental human rights. Article 23(4) of the Universal Declaration of Human Rights (UDHR) guarantees a person "the right to form and to join trade unions for the protection his interests": generally, those interests are most effectively protected through collective bargaining and action. Had Canada honoured its human rights obligations, workers' rights to bargain collectively and to strike should have been unambiguously guaranteed by the Charter,

44 For a discussion of freedom of association, collective action and the right to strike, see Bernard Gernigon, Alberto Odero and Horacio Guido ILO Principles Concerning the Right to Strike (International Labour Office, Geneva, 1998) <www.ilo.org>.

45 See Brian Langille "The Condescending Constitution (or, The Purpose of Freedom of Association is Freedom of Association)" (2016) 19 Canadian Lab \& Emp LJ 335.

46 Canada ratified ILO C138 in 2016, thereby becoming a party to all eight fundamental ILO conventions.

47 Reference Re Public Service Employee Relations Act (Alberta) (1987) 38 DLR (4 $\left.{ }^{\text {th }}\right) 161$.

48 At $233-4$ 
and not left to the Supreme Court to ultimately and, perhaps, reversibly, ${ }^{49}$ recognise. This is an important lesson for New Zealand.

\section{South Africa}

The South African Bill of Rights prohibits slavery, servitude and forced labour. ${ }^{50}$ A right to picket is included in a freedom of assembly guarantee. "Everyone has the right to freedom of association" 52 and "[e]very citizen has the right to choose their trade, occupation or profession freely." ${ }^{53}$ Section 23 , which is the key labour relations guarantee, provides:

1. Everyone has the right to fair labour practices.

2. Every worker has the right-

a. to form and join a trade union;

b. to participate in the activities and programmes of a trade union; and

c. to strike...

5. Every trade union, employers' organisation and employer has the right to engage in collective bargaining ...

Section 27(4) of the 1993 Interim Constitution restricted the right to strike to the purposes of collective bargaining. ${ }^{54}$ This restriction was not carried through into the 1996 Constitution and thereby opened up the possibility for politically-motivated strikes. However, in terms of the Labour Relations Act 1995 (South Africa), striking is only permitted in respect of an unresolved disputes with an employer. ${ }^{55}$ According to Halton Cheadle, this restriction has not been challenged on constitutional grounds. ${ }^{56}$

Martin Brassey and Carole Cooper observe "it is rare to find a constitution that includes the broad and vague rights to a fair labour practice", ${ }^{57}$ but they recognise "labour law already has a kind of charter of fundamental rights of its own". ${ }^{58}$ In this regard, Maralize Conradie demonstrates how a right to fair labour practices can be seen in the context of the gradual erosion of unfair labour practices in the decades before the enactment of the Constitution. ${ }^{59}$

49 See Langille, above $\mathrm{n} 45$.

50 Constitution of the Republic of South Africa 1996, s 13.

51 At s 17. For a discussion of the right to picket, see Brassey and Cooper, above n 31, 30-43-30-44.

52 Constitution of the Republic of South Africa 1996, s 18.

53 At s 22.

54 Employers do not enjoy a corresponding constitutional right to lock out employees in the event of a dispute. See Martin Brassey Employment and Labour Law, Vol 1 Employment Law (Juta \& Co, Cape Town, 1998) at C3:2-C3:4. However, the Labour Relations Act 1995 (South Africa) treats strikes and lock outs evenhandedly.

55 See section 64 of the Labour Relations Act 1995 for the exact circumstances under which a strike is legal.

56 See Halton Cheadle "Constitutionalising the Right to Strike" in Bob Hepple, Rochelle le Roux and Silvana Sciarra (eds) Laws against Strikes: The South African Experience in International and Comparative Perspective (FrancoAngeli, Milan, 2015) 67 at 85. Brassey and Cooper, above n 31, at 30-35 argue the right should be interpreted purposively so that it is restricted to the protection of socio-economic rights, notably terms and conditions of work. This interpretation might still allow strikes to protest, for example, against legislation contrary to workers' interests or perhaps, even, against neoliberal policies.

57 Brassey and Cooper, above $\mathrm{n} 31$, at 30-15.

58 At $30-44$

59 M Conradie "The Constitutional Right to Fair Labour Practices: A Consideration of the Influence and Continued Importance of the Historical Regulation of (Un)fair Labour Practices Pre-1977” (2016) 22(2) Fundamina 63. 
What lessons can be learnt from South Africa, which, since the end of Apartheid, has been active in assuming international obligations, for example, ratifying all the fundamental ILO conventions? First, a Bill of Rights can be more extensive than legislation. Second, the principle of fair labour practices can be seen as a local expression of UN and ILO basic principles.

\section{European Union (EU)}

The EU's Charter of Fundamental Rights ${ }^{60}$ establishes extensive work rights, although these are generally subject to Union law and national laws and practices. ${ }^{61}$ In addition to prohibitions on slavery and forced labour, including human trafficking, ${ }^{62}$ freedom to choose an occupation and engage in work; ${ }^{63}$ equality between men and women; $;{ }^{64}$ the EU "recognises and respects the right of persons with disabilities to benefit from measures designed to ensure their independence, social and occupational integration and participation in the life of the community". ${ }^{65}$

Article 27 provides: "Workers or their representatives must, at the appropriate levels, be guaranteed information and consultation in good time in the cases". Furthermore, in terms of article 28 ,

$[w]$ orkers and employers, or their respective organisations, have ... the right to negotiate and conclude collective agreements at the appropriate levels and, in cases of conflicts of interest, to take collective action to defend their interests, including strike action." $" 66$

"Everyone has the right of access to a free placement service." ${ }^{67}$ In terms of article 30, "Every worker has the right to protection against unjustified dismissal". Article 31 provides: ${ }^{68}$

1. Every worker has the right to working conditions which respect his or her health, safety and dignity.

2. Every worker has the right to limitation of maximum working hours, to daily and weekly rest periods and to an annual period of paid leave.

Article 32 provides: ${ }^{69}$

The employment of children is prohibited. The minimum age of admission to employment may not be lower than the minimum school-leaving age, without prejudice to such rules as may be more favourable to young people and except for limited derogations. Young people admitted to work must have working conditions appropriate to their age and be protected against economic exploitation and any work likely to harm

60 Charter of Fundamental Rights of the European Union 2012/C 326/02.

61 See, generally, Steve Peers and Angela Ward (eds) The European Union Charter of Fundamental Rights (Hart Publishing, Oxford, 2004).

62 Charter of Fundamental Rights of the European Union, above n 60, at art 5.

63 At art 15.

64 At art 23

65 At art 26

66 At art 28

67 At art 29.

68 At art 31(1) and (2).

$69 \quad$ At art 32. 
their safety, health or physical, mental, moral or social development or to interfere with their education.

Article 33 provides: ${ }^{70}$

To reconcile family and professional life, everyone shall have the right to protection from dismissal for a reason connected with maternity and the right to paid maternity leave and to parental leave following the birth or adoption of a child.

\section{Analysis of the Proposed Work Rights in Constitution Aotearoa}

This part of the article analyses how the proposals in Constitution Aotearoa compare with other charters in relation to work rights. As a prelude to this, since New Zealand is a signatory to the three principal human rights instruments, it is pertinent to ask firstly whether the work rights in these basic sets of rights have been met. Compliance is illustrated in tabular form below:

\begin{tabular}{|l|l|l|l|l|}
\hline Right & UDHR & ICCPR & ICESCR & Constitution Aotearoa \\
\hline Freedom from slavery & YES & YES & NO & YES \\
\hline Freedom from discrimination & YES & YES & NO & YES \\
\hline Freedom of association & YES & YES & NO & YES \\
\hline Union formation and membership & YES & YES & YES & YES (by implication) \\
\hline Occupational choice & NO & NO & YES & YES \\
\hline Health and safety & NO & NO & YES & YES \\
\hline Equal pay & YES & NO & NO & $\begin{array}{l}\text { NO (but does include non- } \\
\text { discrimination) }\end{array}$ \\
\hline Just and favourable pay & YES & NO & YES & NO \\
\hline Rest and leisure & YES & NO & NO & NO \\
\hline
\end{tabular}

\section{Comparison of national rights}

\section{a. Canada}

As noted, NZBORA was based on the Canadian ICCPR-style charter. Consequently, any inclusion of ICESCR-style and environmental rights can be considered a progression from the Charter. To reiterate, the Vienna Declaration ${ }^{71}$ illegitimates a cafeteria approach to human rights.

\section{b. Germany}

Germany is, of course, bound by the EU Charter with which the Basic Law must be read. Nevertheless, two features of work rights under the Basic Law are particularly relevant for a constitutional review in New Zealand. First, once respect for equal human dignity is established as the fundamental informing principle of all human rights, all other rights need to be interpreted through the lens of dignity. Second, international promises on workers' rights are realised through the monist doctrine. This flow-through is indicated by the coherence between national laws and ILO conventions.

70 At art 33(2).

71 Vienna Declaration and Programme of Action, above n 17. 


\section{c. South Africa}

The text of the South African Bill of Rights includes and mixes economic, social, cultural and environmental rights, along with traditional civil and political rights. Certainly, engagement with ICESCR-style rights has presented challenges for the Constitutional Court, ${ }^{72}$ but these problems have not proved insurmountable for a judiciary which understands its role in a progressive, constitutional democracy. ${ }^{73}$ The principal lesson to be learnt from South Africa is that we should not shy away from asserting socio-economic rights because of concerns that courts will not be able to give them practical meaning.

\section{Advanced socio-economic rights (EU)}

The EU charter may be considered the state-of-the-art rights charter for work rights. In comparison, Constitution Aotearoa falls short by a wide margin. Ideally, we might want to enshrine rights that, in Baruch Spinoza's phrase, have an eye to eternity - and, of course, rights to life, dignity and fair treatment are 'eternal' - but they would also be capable of change by a three-quarters majority of a unicameral Parliament. Such change may not be easily achieved, ${ }^{74}$ but if, say, striking became obsolete as a tool of collective action, it is not unimaginable that 75 per cent of legislators might agree that it should lose its constitutional guarantee.

\section{Constitution Aotearoa}

Constitution Aotearoa may present a coherent roadmap towards a New Zealand republic, but it is an uninspiring and dismal failure as a bill of rights, particularly with regard to work rights. Where is the engagement with the issues that really matter for people who work, commonly precariously, as employees, as volunteers, as so-called contractors or as care-givers outside the scope of the market?

The provisions of comparator bills and charters of rights have been adduced to demonstrate the timidity of the Constitution Aotearoa proposals. Difficulties faced by courts in enforcing socioeconomic rights are not grounds for denying justiciability to work rights. Work rights may be instrumental in realising autonomy, personhood and dignity but, like other rights, they have their own intrinsic value.

What may lie at the root of Palmer and Butler's apparent textual legerdemain is a desire to restrict rights claims to the vertical relationship between state and citizen. ${ }^{75}$ But work rights have an inherently horizontal dimension. Workers must have the constitutionally guaranteed right to enforce their rights directly against their employers.

We need to compare proposed constitutional rights with existing legal rights - including extant legislative rights into the constitution will protect those rights and prevent back-sliding: for

72 See, for example, Soobramoney v Minister of Health, KwaZulu-Natal [1997] ZACC 17, 1998 (1) SA 765 (CC) on the distribution of finite health resources; Minister of Health v Treatment Action Campaign (TAC) [200] ZACC 15, (2002) 5 SA 721 on the provision of retroviral drugs; Government of the Republic of South Africa v Grootboom 2000 (11) BCLR 1169 (CC) on the right to adequate housing.

73 Compare with Aharon Barak The Judge in a Democracy (Princeton University Press, Princeton (NJ), 2006).

74 Gay marriage equality, which seemed like a consensus issue in metropolitan New Zealand at least, in fact only passed by a 64 percent majority.

75 Article 76 provides:

The Bill of Rights applies only to acts done-

(a) by ... the State:

(b) by any person or body in the performance of any public function, power or duty conferred or imposed on that person or body. 
example, Constitution Aotearoa proposes "satisfactory health and safety conditions", ${ }^{76}$ yet section 3(2) of the Health and Safety at Work Act 2015 is, in part, underpinned by "the principle that workers and other persons should be given the highest level of protection ... as is reasonably practicable" (emphasis added). It must be asked why judges can be entrusted with interpreting principles-based legislation but not a constitutional guarantee of the highest level of protection as is reasonably practicable. Similarly, the Employment Relations Act 2000, which itself is arguably a super-statute, legislates the principles of good faith, and trust and confidence. The inclusion of fair labour practices in the South African Bill of Rights was not revolutionary or exotic but reflected a decades-long movement away from unfair labour practices. Surely, good faith, and trust and confidence would be contextually-appropriate principles worthy of mention in a New Zealand Bill of Rights?

The content of Constitutions is greatly determined by the contexts from which they have emerged. The existential crises of Nazism and Apartheid respectively shaped the German and South African supreme laws; they are fundamentally informed by the respect for human dignity, which was previously denied to certain groups within those societies, and a desire to be fully accepted back into the community of nations. New Zealand has not faced (or cannot remember) such existential crises. ${ }^{77}$ However, the Taylor case on the removal of prisoners' voting rights has demonstrated the fragility of fundamental human rights in a context of Parliamentary supremacy. ${ }^{78}$ Human rights are first mentioned in article 75 of Constitution Aotearoa. In comparison, the German Basic law asserts the fundamental nature of respect for human dignity in article 1(1), and substantive rights under the South African constitution start at section 7. It is unsurprising, then, that the Palmer-Butler consideration of work rights is cursory, arguably dismissive. For sure, the realisation of certain socio-economic rights, such as "the enjoyment of the highest attainable standard of physical and mental health", ${ }^{79}$ can only be achieved by executive government and do not lend themselves to direct justiciability. But that institutional inappropriateness does not mean that courts cannot play a review role over delivery. Furthermore, many work rights are substantively different from other socio-economic rights and do indeed lend themselves to justiciability. Ensuring fair remuneration, safe workplaces, and permitting positive discrimination for historically disadvantaged groups are examples of issues which properly fall within the scope and competence of judicial review.

\section{Conclusion}

In this article, we have outlined the work rights proposed in Constitution Aotearoa and compared them with the rights in both less and more extensive bill of rights. We have argued that constitutionally-enshrined work rights should be contextually-specific, such as the fair labour practices in South Africa which have developed from measures taken to counter unfair practices. Consequently, comparison with other jurisdictions may have limited usefulness. Nevertheless, differences can be seen between the bare, Canadian charter guarantee of freedom of association and the needs of workers. It took the Supreme Court three decades to close this gap, and then, perhaps, imperfectly. Conversely, the EU charter seems unnecessarily specific

76 Compare with article 106(c) of Constitution Aotearoa which proposes "the right of everyone to the enjoyment of the highest attainable standard of physical and mental health" (emphasis added). Surely health and workplace safety are interrelated, perhaps inseparable rights?

77 Ignorant or non-cognisant of the sanguinary New Zealand Wars, the ex-prime minister John Key famously observed that the New Zealand state had emerged without bloodshed. See "What war? Key's abridged history" Stuff (online) 31 July 2009.

78 See Attorney-General v Taylor [2017] NZCA 215 at [149]-[150] on the courts' engaging in a dialogue about human rights with Parliament. (And, on prisoners' voting rights thus far being ignored.)

79 Constitution Aotearoa, art 106(c). 
and might profitably have been left at a level of principle, rather than quasi-regulation. Despite differences, each country considered has committed itself to the three principal human rights instruments, as well as most ILO conventions. And so, in addition to local circumstances, international obligations ought to be taken into account in establishing constitutional guarantees. To reiterate, as affirmed by the Vienna Declaration and Programme of Action, "human rights are universal, indivisible and interdependent and interrelated". ${ }^{80}$

The Bill of Rights proposed in Constitution Aotearoa commendably moves beyond the narrow civil and political rights of NZBORA to include socio-economic, and environmental rights, and makes Parliamentary legislation subject to judicial review on constitutional grounds. But the inclusion of non-ICCPR-style rights seems half-hearted. In particular, the proposal to make work rights non-justiciable lends itself to a resurrected Clayton's comparison. The explanation, "courts will not be able to enforce them; but citizens will be able to draw on them to make State institutions accountable", ${ }^{81}$ unfortunately implies the rights you have when you don't want to have rights. ${ }^{82}$

What the workplace of the future will look like is a matter of speculation but it can be reasonably assumed that the imbalance in negotiating power between labour and the organisation (private or governmental), which Otto Kahn-Freund tells us lies at the root of labour law, ${ }^{83}$ will not disappear. Further, union memberships, collective bargaining and action, including the withdrawal of labour, will, for the foreseeable future, remain the most effective ways of recalibrating this imbalance. And so, bearing in mind rights may be restricted "by law as can demonstrably justified in a free and democratic society", ${ }^{84}$ generous work rights need unambiguous, positive expression - and, by necessity, horizontal effect.

80 Vienna Declaration and Programme of Action, above n 17, at I(5).

81 Palmer and Butler, above n 1, at 171.

82 See Haywood, above n 10.

83 See Otto Kahn-Freund Labour and the Law (Stevens, London, 1972) at 4.

84 Constitution Aotearoa, art 77. 